\title{
27. MIOCENE AND CRETACEOUS TETRAPYRROLE PIGMENTS FROM LEG 44, SITE 391
}

\author{
E. W. Baker ${ }^{1}$, S. E. Palmer ${ }^{2}$, and W.Y. Huang ${ }^{3}$ \\ Department of Chemistry, Northeast Louisiana University, Monroe, Louisiana
}

\section{INTRODUCTION}

DSDP samples from the Blake-Bahama Basin provided an opportunity to study tetrapyrrole geochemistry in sediments of Miocene and Cretaceous age. Miocene samples from Legs 40 and 41 contained chlorins similar to those found in this study (Baker, et al., 1978a, b). Earlier studies of upper Tertiary marine sediment samples contained mixtures of chlorins, free-base, and nickel porphyrins (Smith and Baker, 1974; Baker and Smith, 1975a; and Baker et al., 1976).

Cretaceous sediments of marine origin have been found in some instances to contain chlorins (Baker et al., 1978b; Palmer et al., in press), but more frequently contain mixtures of free-base porphyrins, nickel porphyrins, and sometimes vanadyl porphyrins (Baker and Smith, 1975b; Baker et al., 1978 a, b).

From this survey of earlier data, it becomes apparent that finding chlorins as the predominant pigment is somewhat unique for Cretaceous sediments, especially where the depth of burial is $840-960$ meters. In the other two cases, Legs 41 and 43 , Cretaceous sediments containing chlorins were found at 450 to 880 meters and 414 to 787 meters, respectively (Baker et al., 1978b; Palmer et al., in press).

In this study, 12 Site 391 sediment core samples ranging from Pleistocene to Upper Jurassic were analyzed for tetrapyrrole pigment content. The two most striking findings were (1) the predominance of chlorins over free-base and/or metalloporphyrins and (2) the concentration versus an age-depth profile which shows that the bulk of the pigment occurred in one Miocene (391A-13) and one Cretaceous (391C-10) interval.

\section{EXPERIMENTAL}

Methods used for extraction, isolation, and characterization of geo-pigments have been presented previously (see DSDP Initial Reports, Volumes 38, 40, and 41: Baker et al., 1976, and 1978a, b). Briefly, 100 grams of frozen core sample were ball-milled in acetone:methanol $(9: 1)$ with several solvent changes until the extract was virtually devoid of pigment. The crude extracts were chromatographed on Sephadex LH-20 and eluted with THF. The type and amount of pigment was recorded (see Table 1). UV-visible spectra were recorded using a Beckman ACTA CIII scanning

\footnotetext{
${ }^{1}$ Present address: Florida Atlantic University, College of Science, Boca Raton, Florida.

${ }^{2}$ Florida Atlantic University, Department of Geology, Boca Raton, Florida.

${ }^{3}$ University of New Orleans, Biol. Sci. Dept., New Orleans, Louisiana.
}

spectrophotometer. Diazomethane-derivation followed by sugar and Alumina Grade III chromatography was used for further purification.

Mass spectrometric analyses were made using a DuPont 491-BR mass spectrometer via solid probe on silylated hydroxyaluminum derivatives of chlorins. Methods used for the preparation of the derivatives and mass spectrometric analyses are given in the Initial Reports of the Deep Sea Drilling Project Volume 42B (Baker et al., 1978c).

Mass spectra of the nickel porphyrins were also recorded using the solid probe inlet system. Probe temperatures were $245^{\circ}-265^{\circ} \mathrm{C}$, and source temperatures were $240^{\circ}-265^{\circ} \mathrm{C}$.

\section{Depth-age Profile}

\section{RESULTS}

Individual pigment yields (Table 1) were plotted relative to depth of burial as shown in Figure 1. Chlorins predominate the profile and were most abundant in Core 391 A-13 (Miocene) at 530 meters and in Core 391C-10 (Cretaceous) at 900 meters. Free-base porphyrins were detected in trace amounts (up to 0.05 $\mu \mathrm{g} / \mathrm{g}$ ) in four Miocene cores and one Cretaceous core. Nickel porphyrins were also present in both the Miocene and Cretaceous sediments, but in greater concentrations than the free-base porphyrins. In Core 391C-10, nickel porphyrins were 50 percent as abundant as chlorins.

Only a trace of pigment was found in Core-Section 391C-52-2, the oldest DSDP sample studied to date; not enough data were obtained to assign the pigment to a class of tetrapyrrole.

\section{Chlorins}

Chlorins were characterized in the conventional way by their behavior on gel permeation chromatography, by UV-visible spectrophotometry, and $\mathrm{HCl}$ extraction number. In one case, the newest addition to the repetoire of spectral techniques was applied. The mass spectra of silylated hydroxyaluminum derivatives of chlorin fractions from the Miocene sample from Core 391A-13 were compared with those of model chlorins. Unfortunately, attempts to isolate and purify chlorins from the Cretaceous sample of Core 391C-10 were not as successful.

UV-visible spectral data of pigment fractions are given in Table 1. Two types of chlorins were present in the upper sections (Miocene) as determined by their separation behavior on Sephadex LH-20; an earlyrunning fraction with a red band at $662 \mathrm{~nm}$ and a laterrunning fraction with a red band at $658 \mathrm{~nm}$. The earlyrunning fraction was extractable into 20-32 per cent 
TABLE 1

Tetrapyrrole Pigment Yields From Leg 44, Site 391 Cores

\begin{tabular}{|c|c|c|c|c|c|c|c|c|c|c|c|c|c|c|}
\hline \multirow{2}{*}{$\begin{array}{l}\text { Section } \\
391 \mathrm{~A}-4-3\end{array}$} & \multirow{2}{*}{$\begin{array}{l}\text { Geologic Age }{ }^{\mathrm{a}} \\
\text { Miocene }\end{array}$} & \multirow{2}{*}{$\begin{array}{c}\begin{array}{c}\text { Depth of } \\
\text { Buriala }^{\mathrm{a}} \\
(\mathrm{m})\end{array} \\
200\end{array}$} & \multirow{2}{*}{$\begin{array}{c}\begin{array}{c}\text { Organic } \\
\text { Carbon } \\
(\% \text { by wt) }\end{array} \\
2.30\end{array}$} & \multirow{2}{*}{$\begin{array}{c}\begin{array}{c}\text { Individual } \\
\text { Yield } \\
(\mu \mathrm{g} / \mathrm{g})\end{array} \\
0.01 \\
0.005 \\
0.008\end{array}$} & \multicolumn{9}{|c|}{$\begin{array}{l}\text { UV-Visible Absorption Spectra } \\
\text { (nanometers) }\end{array}$} & \multirow{2}{*}{\begin{tabular}{l}
\multicolumn{1}{c}{ Pigment Type } \\
Chlorin \\
Chlorin \\
Chlorin
\end{tabular}} \\
\hline & & & & & $\begin{array}{l}397 \\
393 \\
393\end{array}$ & 500 & & $\begin{array}{l}(535) \\
(535) \\
(530)\end{array}$ & & (587) & $\begin{array}{l}(595) \\
(595)\end{array}$ & & $\begin{array}{l}662 \\
660 \\
658\end{array}$ & \\
\hline $391 \mathrm{~A}-5-0$ & Miocene & 260 & 0.37 & $\begin{array}{l}0.1 \\
0.03 \\
0.06 \\
\text { trace }\end{array}$ & $\begin{array}{l}402 \\
400\end{array}$ & $\begin{array}{l}500 \\
500 \\
498\end{array}$ & & $\begin{array}{l}(534) \\
(534)\end{array}$ & & $\begin{array}{l}(588) \\
578\end{array}$ & $\begin{array}{l}(600) \\
(595)\end{array}$ & 620 & $\begin{array}{l}662 \\
660 \\
658\end{array}$ & $\begin{array}{l}\text { Chlorin } \\
\text { Chlorin } \\
\text { Chlorin } \\
\text { Free-base porphyrin }\end{array}$ \\
\hline $391 \mathrm{~A}-13-0$ & Miocene & 530 & 1.43 & $\begin{array}{l}0.57 \\
0.39 \\
0.85 \\
0.05 \\
0.03\end{array}$ & $\begin{array}{r}409 \\
402 \\
394-8 \\
393\end{array}$ & $\begin{array}{l}495 \\
490 \\
497\end{array}$ & 525 & 532 & 547 & & $\begin{array}{l}602 \\
600\end{array}$ & 618 & $\begin{array}{l}664 \\
663 \\
658\end{array}$ & $\begin{array}{l}\text { Chlorin } \\
\text { Chlorin } \\
\text { Chlorin } \\
\text { Free-base porphyrin } \\
\text { Nickel porphyrin }\end{array}$ \\
\hline $391 \mathrm{~B}-2-1$ & Pleistocene & 3 & $?$ & 0.01 & 402 & & & & & & & & 664 & Chlorin \\
\hline $391 c-6-3$ & Late Cretaceous & 690 & 0.91 & trace & 392 & & & & & & & & & Metalloporphyrin \\
\hline $391 C-9-3$ & $\begin{array}{l}\text { Albian } \\
\text { Early Cretaceous }\end{array}$ & 840 & 0.23 & $\begin{array}{l}0.36 \\
0.03\end{array}$ & 390 & & 515 & & 548 & & & & 660 & $\begin{array}{l}\text { Chlorin } \\
\text { Nickel porphyrin }\end{array}$ \\
\hline $391 C-10-3$ & $\begin{array}{l}\text { Albian } \\
\text { Early Cretaceous }\end{array}$ & 900 & 1.53 & $\begin{array}{l}0.63 \\
0.31 \\
0.03\end{array}$ & $\begin{array}{l}395 \\
390 \\
396\end{array}$ & 498 & $\begin{array}{l}515 \\
520\end{array}$ & & 548 & (575) & & 618 & 660 & $\begin{array}{l}\text { Chlorin } \\
\text { Nickel porphyrin } \\
\text { Free-base porphyrin }\end{array}$ \\
\hline $391 C-12-4$ & $\begin{array}{l}\text { E. Albian } \\
\text { Aptian } \\
\text { Early Cretaceous }\end{array}$ & 960 & 1.66 & 0.05 & 390 & & 515 & & 548 & & & & $656-58$ & $\begin{array}{l}\text { Chlorin } \\
\text { Nickel porphyrin }\end{array}$ \\
\hline $391 C-52-2$ & Late Jurassic & 1390 & 0.59 & trace & 412 & & & & & & & & & $?$ \\
\hline
\end{tabular}

a Data obtained from Leg 44 Hole Summary.

b Pigment yields calculated by using the following molar extinction coefficients: pheophytin "a" $=63700$ at $660 \mathrm{~nm}$, free-base porphyrin $=6540$ at $618 \mathrm{~nm}$, and nickel porphyrin $=34820$ at $550 \mathrm{~nm}$.

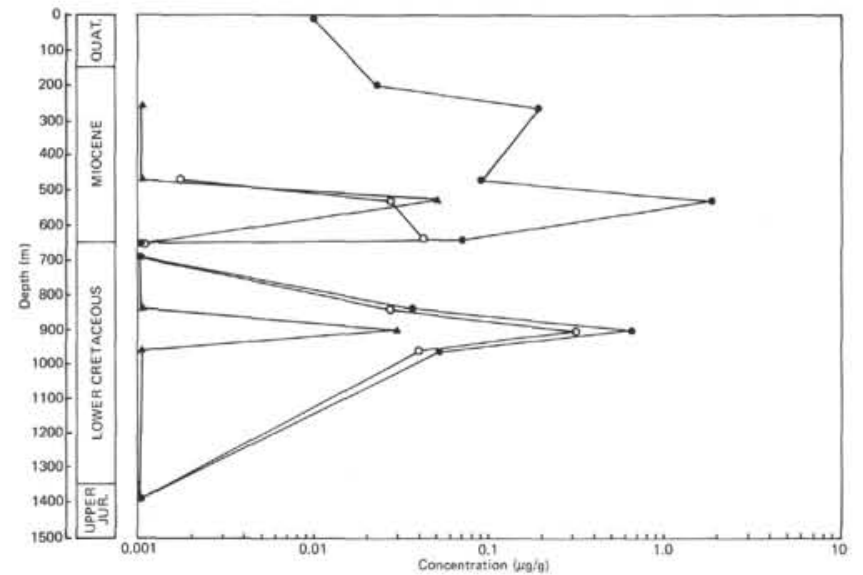

Figure 1. Depth of burial/age profile, Site 391. Pigment concentration (log scale) is plotted versus depth of burial data for chlorins $(\bullet)$, free-base porphyrins $(\mathbf{\Delta})$, and nickel porphyrins (0) plotted here are given in Table 1. Stratigraphy was supplied by DSDP.

$\mathrm{HCl}$ while the later fraction extracted into $10-20$ per cent $\mathrm{HCl}$. With increasing depth of burial, the disappearance of the early eluting fraction was noted. These results are similar to those reported for chlorins extracted from Pleistocene Black Sea sediments; as depth-age increased only the later-running fraction with the lower $\mathrm{HCl}$ number was found (Baker et al., 1978c).

Mass spectrometric data of chlorins from the Miocene core sample, 391A-13, are given in Table 2. Both the early- and late-running Sephadex fractions had mass spectra indicative of either pheophytin a, pheophorbide a, or pyropheophoribe a. These results are similar to those obtained for chlorins of Pleistocene age from Black Sea sediments. The data indicate that chlorins with a ruptured isocyclic ring, such as chlorin $\mathrm{e}_{6}$, and chlorins with a C-2 vinyl group and lacking the 9-keto and 10-carbomethoxy groups (deoxomesopyropheophorbide) are absent. This method does not allow any indication for the presence or absence of phytol. However, the high HCL extraction number (20\%-32\%) of the early-running Sephadex fraction does suggest that these are pheophytin-type chlorins. The laterrunning fraction may lack phytol; the lower $\mathrm{HCl}$ number is indicative of pheophorbide or pyropheophorbide (Table 3). Having a phytol side chain makes pheophytin more lipophilic thus lowering its affinity for the aqueous phase. Without this side chain, the affinity for the aqueous phase increases and the percent $\mathrm{HCl}$ necessary for extraction decreases. Fischer and Stern (1940) gave the following $\mathrm{HCl}$ numbers for chlorins: pheophytin a $(\mathrm{HCl} \mathrm{no.}=28-29)$, pheophorbide a $(\mathrm{HCl} \mathrm{no.}=15)$, and pyropheophorbide a $(\mathrm{HCl}$ no. $=12-13)$. 
TABLE 2

Mass Spectrometric Data of Silylated Hydroxyaluminum Derivatives of Leg 44 Geochlorins, Core 391A-13

\begin{tabular}{lccccc}
\hline $\begin{array}{l}\text { Sephadex } \\
\text { Fraction }\end{array}$ & $\begin{array}{c}\text { Approx. } \\
\text { HCl No. (\%) }\end{array}$ & \multicolumn{4}{c}{$\begin{array}{c}\text { Mass Spectrum of } \\
\text { Silyl Derivative }\end{array}$} \\
$\begin{array}{l}\text { Early running } \\
\text { Late running }\end{array}$ & $20-32$ & 720 & 712 & 664 \\
\hline Note: Mass spectrometric data of silylated hydroxy- \\
aluminum chlorins and model chlorins discussed in \\
the text are reported in Baker et al., in press c.
\end{tabular}

The degree of de-esterification and reduction increases with increasing depth of burial as evidenced by the disappearance of the chlorins having high $\mathrm{HCI}$ numbers which give way to those with lower numbers. The relative simplicity of the mass spectra (see Table 2) places a limit on the possible number of components present in the isolated chlorin fractions. Even though a mixture of esterified and de-esterified chlorins could be present and would not be discerned mass spectrometrically, chlorins with extensive structural differences cannot be present.

The simplest possible chlorin diagenetic scheme would involve only pheophytin a, pheophorbide and pyropheophorbide (Treibs, 1936). Very recently, workers have proposed a much more complex diagenetic scheme involving the early appearance of chlorin homologs (Casagrande and Hodgson, 1976). The evidence presented here and by Baker et al. (1978c) indicate that the actual case is only slightly more complicated than the Treibs proposal, but not in any way suggestive of the complex scheme described by Casagrande and Hodgson. Specifically, no indication of even incipient formation of homologous series of chlorins was detected. Neither a diagenetic sequence nor a biological source other than chlorophyll a need be invoked to account for the observed results.

\section{Porphyrins}

Small amounts of free-base porphyrins were present in cores containing sediment of Miocene and Cretaceous age; their UV-visible spectra are reported in Table 1 and their distribution is shown in Figure 1. Sufficient quantity of free-base porphyrin $(0.03 \mu \mathrm{g} / \mathrm{g})$ was present in Core 391C-10 to allow us to isolate and record the visible spectrum. The UV-visible spectrum is of the DPEP-type, similar to those reported for Cretaceous samples from Legs 40 and 41 (Baker et al., $1978 \mathrm{a}, \mathrm{b})$. Insufficient material was available for mass spectrometric analysis.

Nickel porphyrins of the DPEP and etio type were present in Miocene and Cretaceous sediments, and were approximately one-half as abundant as chlorins in Core 391C-10. Demetallation of the Core 391C-10 nickel porphyrin fraction yielded a pigment with a DPEP-type visible spectrum with indications of lesser amounts of etio-type porphyrins being present.

\section{Mass Spectrometric Analyses of Nickel Porphyrins}

One Miocene (391A-21) and three Cretaceous cores (391C-9, -10, and -12) contained sufficient nickel porphyrin for mass spectrometric analyses. The data are given in Table 3. Porphyrins of the DPEP series predominated in Core 391C-10; the DPEP/etio ratio is 1.2. Nickel porphyrins of the etio series made a larger contribution in Core $391 \mathrm{C}-12$ as indicated by the lower DPEP/etio ratio of 0.74 .

The nickel porphyrin fractions from Cores 391A-21 and 391C-9 did not contain a nickel DPEP homologous series. The etio series was present, but secondary in abundance to another series of nickel porphyrins. This series, also present in Cores 391C-10 and -12, has values seven mass units distant from the DPEP series. In support of the mass spectral data, we also noted a subtle variance from the normally expected nickel DPEP and etio-type visible spectra. The $\alpha / \beta$ ratio $=2.0$ ). The $\alpha / \beta$ ratio for nickel etioporphyrin is 3.4. No interpretation of these data is made at this time. However, homologous series of nickel porphyrins of this type were also found in the deeper Pleistocene, Pliocene, and Miocene sediment samples of the Black Sea and in Eocene to Cretaceous samples off Bermuda (Leg 43) (Baker et al., 1978c; Palmer et al., in press).

\section{DISCUSSION}

The tetrapyrrole fraction of organic extracts from the Miocene and Lower Cretaceous samples of Site 391 consisted of chlorins ( $56 \%$ to $100 \%)$, free-base porphyrins (trace to $3 \%$ ), and nickel porphyrins (1.5\% to $43 \%$ ). The predominance of free-base chlorins in these sediments is indicative of a mild thermal history. Cretaceous sediments of comparable depths of burial (Leg 41) contained chlorins similar to those described here. In contrast, Cretaceous sediments at 1000 meters plus (Leg 40) contained predominantly metalloporphyrins with lesser amounts of free-base porphyrins. Greater thermal stress and depth of burial would account for the occurrence of later diagenetic products (metalloporphyrins) in the Leg 40 samples.

Mass spectrometric data of silylated hydroxyaluminum derivatives of chlorins from the Miocene sample of Core 391A-13 were similar to those obtained for Pleistocene samples from the Black Sea. The similarities between these data further strengthen the suggestion that diagenesis is still at an early stage.

The "reductive pathway" leading from dihydrophytolpheophorbide a to DPEP-type porphyrins is suggested by the presence of pheophytin or pheophorbide type chlorins, free-base porphyrins with a DPEP-type visible spectrum, and nickel DPEPtype porphyrins. Chlorins having a ruptured isocyclic ring which are attributed to the "oxidative pathway" were not found by mass spectrometry of hydroxyaluminum derivatives.

The predominance of the nickel DPEP series, as shown by the high DPEP/etio ratio $(=1.2)$ in Core $391 \mathrm{C}-10$, is indicative of mild thermal conditions (Table 3 ). However, the etio series is much more pronounced in Core 391C-12; the DPEP/etio ratio is comparatively low $(=0.74)$, and the number of etio series homologs is greater. These findings suggest either (1) thermal alteration of nickel DPEP to nickel etio, (2) reworking, or (3) operation of "oxidative pathway." We reject that thermal alteration was a factor because the presence of twice as much chlorin as nickel porphyrin is 
TABLE 3

Mass Spectrometric Data of Nickel Porphyrins From Site 391 Cores

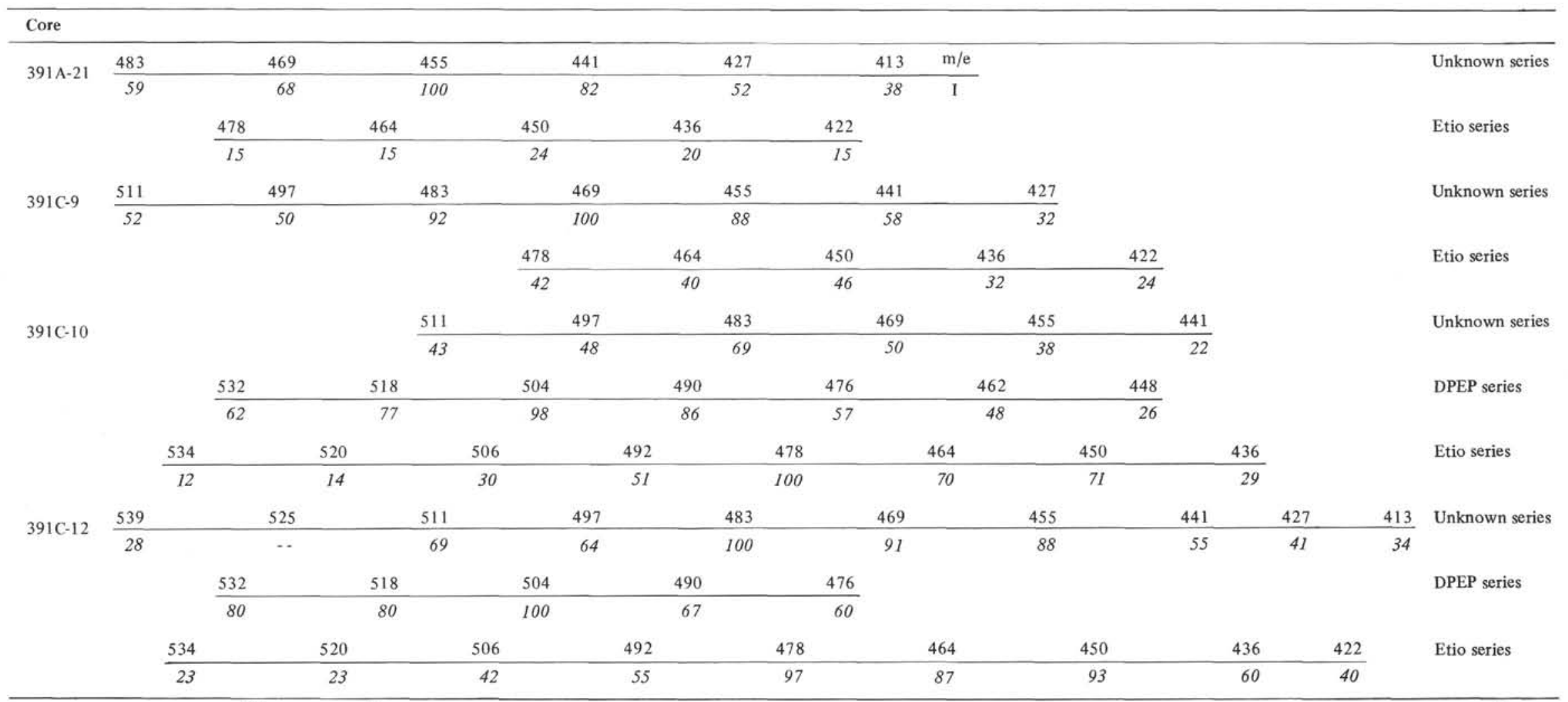

${ }^{\mathrm{a}}$ The peak heights (I) for the $\mathrm{Ni}^{58}$ DPEP and $\mathrm{Ni}^{58}$ etio series have been normalized so that the largest peak is equal to 100 (shown in italics). The values for the etio series have been adjusted for the $\mathrm{Ni}^{60}$ isotope contribution from the corresponding nickel DPEP; the corrected values were used to compute the normalized values in the table. Non-etio or DPEP nickel porphyrin series have also been normalized. 
consistent with only a mild thermal history. The "oxidative pathway" which leads to porphyrins of the etio series with carbon skeletons less than that of etioporphyrin $\left(\mathrm{C}_{32}\right)$ does not account for the total molecular weight range observed (Table 3). Therefore, reworking of the sediment appears to be the most likely explanation; mixing of the more mature nickel etioporphyrins with the immature chlorin-nickel DPEP series could account for this particular assortment of pigments.

\section{CONCLUSIONS}

The tetrapyrrole pigment characteristics outlined above clearly indicate that the Miocene and Cretaceous sediments of Site 391 have experienced only a mild thermal history. We draw this conclusions on the basis of the following findings:

1) Predominance of chlorins over metalloporphyrins. 2) Predominance of nickel DPEP over nickel etio series in Cretaceous cores, and

3) The lack of high molecular weight porphyrins (greater than $\mathrm{C}_{32}$ ), particularly transalkylated vanadyl porphyrins.

We conclude that these are an immature suite of pigments and that their presence in cores of Site 391 indicates burial temperatures of less than $100^{\circ} \mathrm{C}$.

\section{ACKNOWLEDGMENTS}

This research was supported by the Oceanography Section of the National Science Foundation, Grants DES 74-12438 A01 and OCE 74-12438 A02. We kindly thank Dr. Karl. S. Schorno, Phillips Petroleum Company, Bartlesville, Oklahoma, for his review of the manuscript.

\section{REFERENCES}

Baker, E.W. and Smith, G.D., 1973. Chlorophyll derivatives in sediments, Site 147. In Heezen, B.C., MacGregor, I., et al., Initial Reports of the Deep Sea Drilling Project, Volume 15: Washington (U.S. Government Printing Office), p. 943.

, 1975a. Chlorophyll derivatives in DSDP Leg 31 sediments. In Ingle, J.C., Karig, D.E., et al., Initial Reports of the Deep Sea Drilling Project, Volume 31: Washington (U.S. Government Printing Office), p. 629.
, 1975b. Chlorophyll derivatives in DSDP Legs 12, 20, 26, 27, and 29 sediments. In Ingle, J.C., Karig, D.E., et al. Initial Reports of the Deep Sea Drilling Project, Volume 31: Washington (U.S. Government Printing Office), p. 905 .

Baker, E.W., Palmer, S.E., and Parrish, K.L., 1976. Tetrapyrrole pigments in DSDP Leg 38 sediments. In Talwani, M., Udintser, G., et al., Initial Reports of the Deep Sea Drilling Project, Volume 38: Washington (U.S. Government Printing Office), p. 785-790.

Baker, E.W., Palmer, S.E., and Huang, W.Y., 1978a. Chlorin and porphyrin geochemistry of DSDP Leg 40 sediments. In Bolli, H.M., Ryan, W.B.F., et al., Initial Reports of the Deep Sea Drilling Project, Supplement to Volumes 38, 34, 40, and 41: Washington (U.S. Government Printing Office), p. 639-648.

$1978 \mathrm{~b}$. Intermediate and late diagenetic tetrapyrrole pigments, Leg 41: Cape Verde Rise and Basin. In Lancelot, Y. Seibold, E., et al., Initial Reports of the Deep Sea Drilling Project, Volume 41: Washington (U.S. Government Printing Office), p. 825-838. 1978c. Early and intermediate chlorophyll diagenesis of Black Sea sediments: Sites 379, 380, and 381. In Ross, D., Neprochnov, Y., et al., Initial Reports of the Deep Sea Drilling Project, Volume 42, Part 2: Washington (U.S. Government Printing Office), p. 707-716.

Casagrande, D.J. and Hodgson, G.W., 1976. Geochemistry of porphyrins: the observation of homologous tetrapyrroles in a sediment sample from the Black Sea: Geochim. Cosmochim. Acta., v. 40, p. 479.

Fischer, H. and Stern, A., 1940. Die Chemie de Pyrrols, Band II: Pyrrolfarbstoffe, Halfte 2: Leipzig (Akad. Verlag.), p. 55,59 , and 73 .

Palmer, S.E., Huang, W.Y., and Baker, E.W., 1978. Tetrapyrrole pigments from Bermuda Rise: DSDP Leg 43. In Tucholke, B., Vogt, P., et al., Initial Reports of the Deep Sea Drilling Project, Volume 43: Washington (U.S. Government Printing Office).

Smith, G.D. and Baker, E.W., 1974. Chlorophyll derivatives in DSDP Leg 22 sediments. In von der Borch, C.C., Sclater, J.G., et al., Initial Reports of the Deep Sea Drilling Project, Volume 22: Washington (U.S. Government Printing Office), p. 677.

Treibs, A., 1936. Chlorophyll and Haminderivate in Organischen Mineral-stoffen: Angew. Chem., v. 49, p. 682 . 